\title{
SPECTROPHOTOMETRIC DETERMINATION OF ESZOPICLONE IN PURE AND PHARMACEUTICAL FORMS
}

\author{
CHENNAIAH M $M^{1}$, VEERAIAH T $T^{2}$ AND VENKATESHWARLU ${ }^{* 1}$ \\ ${ }^{1}$ Department of Chemistry, Nizam College (O.U.), Hyderabad, 500001, India \\ ${ }^{2}$ Department of Chemistry, SAP College Vikarabad, Ranga Reddy, Andhra Pradesh, 501101, India
}

\begin{abstract}
Six spectrophotometric methods for determination of eszopiclone have been developed, validated and applied for the assay of the drug in pharmaceuticals. Methods A, B, C and D are based on ion pair complexation of drug, in acidic buffers, with triphenylmethane dyes viz., Bromothymol blue(BTB), Bromophenol blue(BPB), Bromocresol green(BCG) and Bromocresol purple(BCP). The complexes are extracted into chloroform and absorbance is measured around at 415 $\mathrm{nm}$ as function of concentration of the drug. The stoichiometry of the complex is found 1:1 in each case. Method E depends upon charge transfer complexation of neutralized drug with iodine which produces iodide ion whose absorbance at $366 \mathrm{~nm}$ is measured as function of concentration of the drug. This complex, too, has 1:1 composition as determined by Job's method. Method $\mathrm{F}$ is developed on the basis of oxidation of the drug with alkaline $\mathrm{KMnO}_{4}$ which generates green colored manganate ion with $1_{\max } 610 \mathrm{~nm}$. As the intensity of green color increased with increasing time kinetics of the reaction is followed and calibration curves are constructed by using initial rate and fixed time methods. Excellent recovery studies with high accuracy and precession indicate that the methods can be successfully used in industries for the assay of drug in pure form and pharmaceuticals.
\end{abstract}

Key-words: Spectrophotometry, Eszopiclone, Bromothymol blue, Bromophenol blue, Bromocresol green, Bromocresol purple, Iodine, $^{\mathrm{Alkaline}_{\mathrm{KMnO}}}$

\section{INTRODUCTION}

Eszopiclone chemically (S)-6-(5-Chloro-2-pyridinyl)-7-oxo-6,7-dihydro$5 H$-pyrrolo $[3,4 b]$ pyrazin5-yl-4-methyl-1-piperazinecarboxylate (I), is a nonbenzodiazepine hypnotic agent used as a treatment for insomnia.

Eszopiclone is the active dextrorotatory stereoisomer of zopiclone, and belongs to the class of drugs known as cyclopyrrolones. Eszopiclone is a short acting nonbenzodiazepine sedative hypnotic[1]. Eszopiclone is a hypnotic agent with a chemical structure unrelated to benzodiazepines, barbiturates, or other drugs with known hypnotic properties, it interacts with the gammaaminobutyric acid-benzodiazepine $\left(\mathrm{GABA}_{\mathrm{B}} \mathrm{Z}\right)$ receptor complex. Subunit modulation of the $\mathrm{GABA}_{\mathrm{B}} \mathrm{Z}$ receptor chloride channel macromolecular complex is hypothesized to be responsible for some of the pharmacological properties of benzodiazepines, which include sedative, anxiolytic, muscle relaxant, and anticonvulsive effects in animal models. Eszopiclone binds selectively to the brain alpha subunit of the GABA A omega-1 receptor[2]. Literature review reveals that some analytical methods have been reported for Eszopiclone by UV and difference spectroscopic methods [3], in biological fluids using LCMSMS [4], validated LC method for the estimation of Eszopiclone in bulk and tablet dosage form [5]. Recently stability indicating RP-LC method for determination of Eszopiclone has been reported which is either tedious or expensive method [6]. The LC method uses acetonitrile as the mobile phase which is expensive than methanol as a mobile phase. Recently EZP has also been quantified and validated by Stability-Indicating HPLC assay method [7].

In the present short communication we report six quantification methods viz., A,B,C.D,E and F have been developed and validated for quantification of the Eszopiclone (EZP) both in pure and pharmaceutical forms.

\section{EXPERIMENTAL}

\section{INSTRUMENTS}

The spectra were recorded on SHIMADZU 140 double beam spectrophotometer, Thermo Nicolet 1000 and also on ELICO 159 UV-Visible single beam spectrophotometers using quartz cells of $10 \mathrm{~mm}$ path length. An Elico model Li-120 $\mathrm{pH}$ meter was used for $\mathrm{pH}$ measurement.

\section{MATERIALS}

HPLC grade chloroform and Analytucal grade (AR) dyes viz., a) BTB b) BPB c) BCG d) BCP were used in the study. Other chemicals such as $\mathrm{HCl}$, Sodium acetate, $\mathrm{KMnO}_{4}$ and Sodium hydroxide are $\mathrm{AR}$ grade and are supplied by Sd Fine Chemicals, Mumbai were used in the study. Iodine (BDH, Poole, $\mathrm{UK})$ was twice sublimed and preserved in vacuum desiccators $\left(\mathrm{mp} 113.6^{\circ} \mathrm{C}\right)$. Iodine in 1,2 dichloroethane was freshly prepared (daily) by dissolving $254 \mathrm{mg}$ solute in $50 \mathrm{ml}$ of solvent $\left(4.0 \times 10^{-3} M\right)$. The drug was procured from Hetero drugs private limited, Hyderabad, as gift sample.

\section{METHODS A, B, C and D}

The methods A,B,C and D are based on the interaction of the drug with Bromothymol blue (BTB), Bromophenol blue (BPB), Bromocresol green (BCG) and Bromocresol purple (BCP) respectively, to form chloroform extractable ion pair complexes (Scheme1) which absorb around $415 \mathrm{~nm}$. The absorbance of this band increases with increasing the concentration of the drug and formed a basis for the quantification of the drug. The dyestuffs were used as $0.025 \%$ solutions in doubly distilled water. Sodium acetate-hydrochloric acid buffers of $p \mathrm{H} 2.8,2.5,3.5$ and 2.5 were prepared by mixing $50 \mathrm{ml}$ of $1.0 \mathrm{M}$ sodium acetate solution with $49.50 \mathrm{ml}, 50.50 \mathrm{ml}, 46.25 \mathrm{ml}$ and $50.50 \mathrm{ml}$ of 1.0 $\mathrm{M} \mathrm{HCl}$ solution respectively and diluted to $250 \mathrm{ml}$ with doubly distilled water. The $\mathrm{pH}$ of each solution was adjusted to an appropriate value with the aid of a $p \mathrm{H}$ meter.

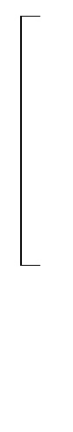

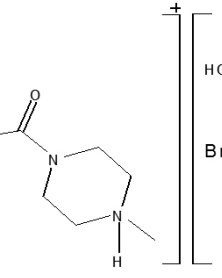<smiles>[R1]C1=CC(=C(c2ccccc2[R5])c2cc([R7])c(O)c(Br)c2[R2])C([R6])=C(Br)C1=O</smiles>

Scheme 1 -E szopiclone-dye complex

Bromothymol blue : $\mathrm{R}_{1}=$ is oporopy $1, \mathrm{R}_{2}=-\mathrm{CH}_{3}$ Bromophenol blue : $\mathrm{R}_{1}=-\mathrm{Br}, \mathrm{R}_{2}=-\mathrm{H}$ Bromocresolgreen $. \mathrm{R}_{1}=-\mathrm{Br}, \mathrm{R}_{2}=-\mathrm{CH}$ Bromocresol purple: $\mathrm{R}_{1}=-\mathrm{CH}_{3}, \mathrm{R}_{2}=-\mathrm{H}$

Sheme 1

\section{METHOD E}

The method depends up on the interaction of drug with Iodine that generates iodide ion having an absorption band at $366 \mathrm{~nm}$. The absorbance of this band increases with increasing the concentration of the drug and formed a basis for the quantification of the drug. Mixing the solution of iodine prepared in DCE with EZP resulted in a change of violet color of iodine into light brown to pale yellow color and as a consequence, absorption spectra exhibited a band of $366 \mathrm{~nm}$. This is attributed due to $\mathrm{I}_{3}^{-}$ion formed by the interaction of iodine with drugs and the same is shown in Scheme 2.

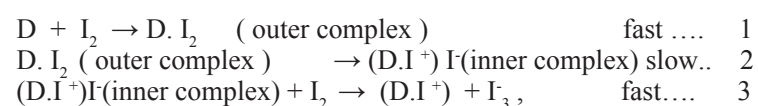

Scheme 2 


\section{METHOD F}

Kinetic method: The method depends on the oxidation of the drug with alkaline $\mathrm{KMnO}_{4}\left(1 \times 10^{-2} \mathrm{M}\right)$ to produce Manganate ion which absorbs at 610 $\mathrm{nm}$ and formed a basis for quantification of drug. A solution of $0.45 \mathrm{M} \mathrm{NaOH}$ is used to produce required alkalinity. Mixing the solutions of permanganate and the drug slowly developed green colour and hence kinetics of the reaction was followed spectrophotometrically with a view to develop a method for the quantitative determination of the drug. The initial rate and fixed time methods are followed for the determination of Eszopiclone. The reaction is shown in Scheme 3 .<smiles>CN1CCN(C(=O)O[C@H]2c3nccnc3C(=O)N2c2ccc(Cl)cn2)CC1</smiles>

Scheme 3

\section{Calibration curves for method A,B,C and D}

Different aliquots of drug solution were transferred into $125 \mathrm{ml}$ separating funnel. To this $5 \mathrm{ml}$ of buffer, $5 \mathrm{ml}$ of dye were added and total volume was made up to $20 \mathrm{ml}$ with water. $10 \mathrm{ml}$ of chloroform was added and the contents were shaken for $5 \mathrm{~min}$. The two layers were allowed to separate for $5 \mathrm{~min}$. The organic layer was separated and absorbance of yellow colored solution which is stable at least for $3 \mathrm{hrs}$ is measured at $415 \mathrm{~nm}$ against blank similarly prepared. The same procedure of analysis is followed either for assay of pure drug or for dosage form. The calibration graphs are linear for all the dyes analysed using these methods.

\section{Calibration curve for method $\mathbf{E}$}

Into separate $10 \mathrm{ml}$ of volumetric flasks different aliquots of EZP solution was transferred followed by the addition of $1 \mathrm{ml}$ of iodine solution prepared in 1,2-dichloroethane $\left(4.0 \times 10^{-3} \mathrm{M}\right)$. The volume was completed using the same solvent and the absorbance was measured against reagent blank at $366 \mathrm{~nm}$.

\section{Calibration curve for method $F$}

A) Initial rate method

Aliquots of 1 to $8 \mathrm{ml}$ of Eszopiclone solution containing $2.5 \mathrm{mg} \mathrm{ml}^{-1}$ of drug were pipetted into a series of $10 \mathrm{ml}$ standard flasks. To each flask, $1.0 \mathrm{ml}$ of $0.45 \mathrm{M} \mathrm{NaOH}$ and $1 \mathrm{ml}$ of $1.00 \mathrm{x} \square 10^{-2} \mathrm{M}$ potassium permanganate were added successively and then diluted with distilled water at $25 \pm \square 10^{\circ} \mathrm{C}$. The contents of each flask were mixed well, and the increase in absorbance as a function of time was measured at $610 \mathrm{~nm}$. The initial rate of the reaction $(v)$ at different concentrations was evaluated by measuring the slope of the tangent to the absorbance-time plot. The calibration graphs were obtained by plotting the initial rate of reaction $(v)$ versus the molar concentration of the Eszopiclone.

\section{B) Fixed time method}

A fixed time of $15 \mathrm{~min}$ was selected for the fixed time method. At this time the absorbance of reaction mixture was measured at $610 \mathrm{~nm}$ against a reagent blank prepared similarly without the drug. The calibration curve was obtained by plotting the absorbance against the initial concentration of Eszopiclone ( Fig1).

Procedure for the assay of pure drug

Four different solutions of pure drug in the range of calibration curve were selected and the recovery experiments were performed. The recoveries and their relative standard deviation is tabulated Table 2 .

\section{Procedure for the assay of dosage forms}

Ten tablets of Lunesta $3 \mathrm{mg}$ are powdered and dissolved in doubly distilled water and stirred thoroughly, filtered through a Whatman No. 42 filter paper. This solution was transferred into $100 \mathrm{ml}$ standard volumetric flask and diluted with doubly distilled water as required. Different solutions of drug in the range of calibration curve were chosen and the assay was estimated using the calibration curve. The results of the recovery experiments are tabulated in Table 3.

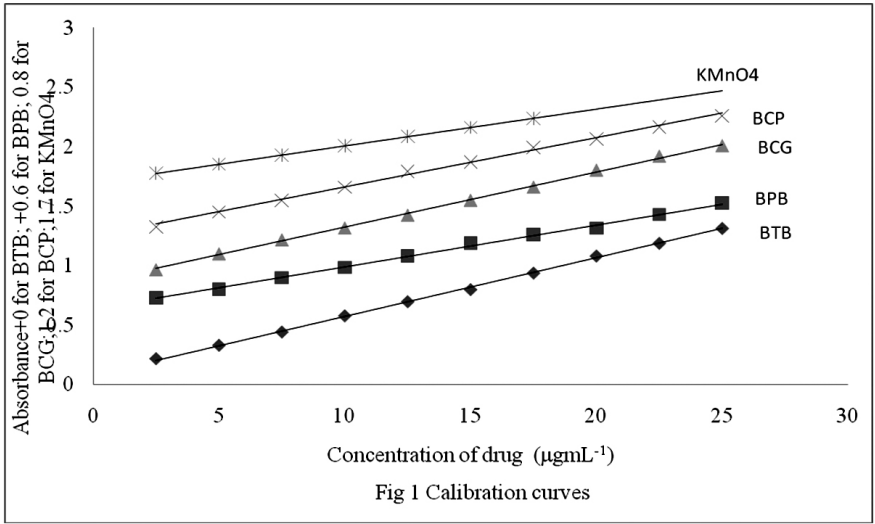

\section{RESULTS AND DISCUSSION}

\section{METHODS A, B, C and D}

EZP forms ion-pair complexes in acidic buffer with dyestuffs viz., $\mathrm{BTB}, \mathrm{BPB}, \mathrm{BCG}$ and $\mathrm{BCP}$ These complexes are quantitatively extracted into chloroform. Ion-pair complexes of drug with dyes absorbed maximally at 415 $\mathrm{nm}$ (Fig. 1). The reagent blank under similar conditions showed no absorption. EZP contains six nitrogen atoms to act as donor sites. But three of them are secondary and formed part of the heterocyclic ring Out of the remaining three , two nitrogens are adjacent to carbonyl and have less basicity. The nitrogen in pyrazine ring is only potential donor site. Hence we propose the protonation of tertiary nitrogen of pyrazine ring in acidic medium, while sulphonic acid group is present in any of the dyes that is the only group undergoing dissociation in the $p \mathrm{H}$ range 1-5. The colour of such dyes is due to the opening of lactoid ring and subsequent formation of quinoid group. It is supposed that the two tautomers are present in equilibrium but due to strong acidic nature of the sulphonic acid group, the quinoid body must predominate. Finally the protonated EZP forms ion-pairs with the dyestuff which is quantitatively extracted into chloroform.

\section{Stoichiometry}

In order to establish molar ratio between EZP and dyestuffs used, the Job's method of continuous variation has been applied [8]. In this method, solutions of drug and dyestuff with identical molar concentrations $\left[8 \times 10^{-5} \mathrm{M}\right]$ were mixed in varying volume ratios in such a way that the total volume of each mixture was the same. The absorbance of each solution was measured and plotted against the mole fraction of the drug, $[\mathrm{drug}] /[\mathrm{drug}]+[$ dyestuff $]$. This measurement showed that 1:1 complex was formed.

The Job's method of stoichiometry is also applied for Iodine with EZP which indicated the charge transfer complex formed is of 1:1 composition (Fig 2).

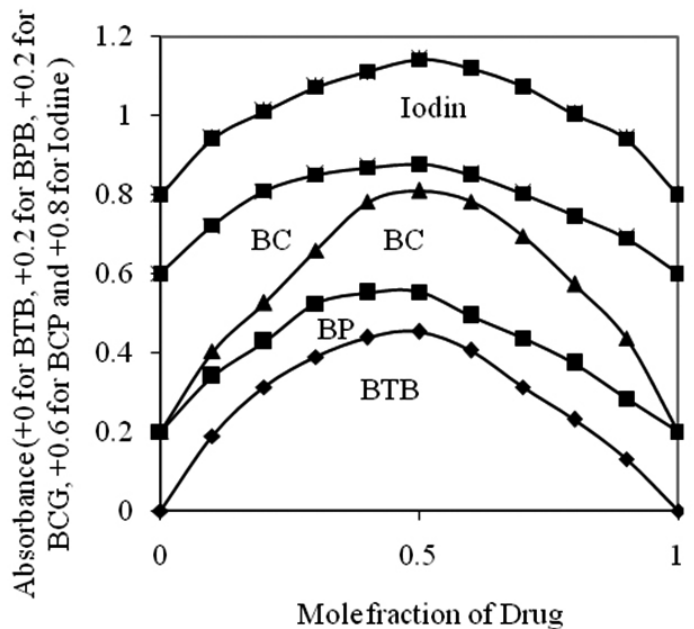

Fig 2 Jpbs continuous variation plots 
Table 1: Spectral and Analytical parameters for the determination of EZP using different methods.

\begin{tabular}{|l|c|c|c|c|c|c|}
\hline \multicolumn{1}{|c|}{ Parameter/Method } & A & B & C & D & E & F \\
\hline$\lambda$ max $(\mathrm{nm})$ & 414 & 411 & 417 & 405 & 610 & 366 \\
\hline Beer's law limits $\left(\mu \mathrm{g} \mathrm{ml}^{-1}\right)$ & $2.2-25$ & $2.5-25$ & $2.5-25$ & $2.5-25$ & $2.5-17.5$ & $18-162$ \\
\hline Molar Absorptivity $\left(\mathrm{L} \mathrm{Mol}^{-1} \mathrm{~cm}^{-1}\right)$ & 19168 & 13725 & 18079 & 18001 & 9603 & 2216 \\
\hline Formation Constant $\left(\mathrm{K}, \mathrm{M}^{-1}\right)$ & $1.724 \times 10^{6}$ & $1.436 \times 10^{6}$ & $1.68 \times 10^{6}$ & $1.57 \times 10^{6}$ & & $1.12 \times 10^{6}$ \\
\hline Sandell Sensitivity $\left(\mu \mathrm{g} \mathrm{cm}^{-2}\right)$ & 0.02 & 0.0283 & 0.0215 & 0.0216 & 0.04 & 0.175 \\
\hline Slope $(\mathrm{a})$ & 0.049 & 0.0353 & 0.0465 & 0.0463 & 0.0247 & 0.0057 \\
\hline Intercept $(\mathrm{b})$ & 0.0804 & 0.0363 & 0.0587 & 0.0415 & 0.0684 & 0.0044 \\
\hline Correlation coefficient $(\mathrm{r})$ & 0.9996 & 0.999 & 0.999 & 0.999 & 0.999 & 0.999 \\
\hline Limit of detection $\left(\mu \mathrm{g} \mathrm{ml}{ }^{-1}\right)$ & 0.27 & 0.27 & 0.27 & 0.27 & 0.27 & 2.0 \\
\hline Limit of quantification $\left(\mu \mathrm{g} \mathrm{ml}{ }^{-1}\right)$ & 0.83 & 0.83 & 0.83 & 0.83 & 0.83 & 6 \\
\hline Regression equation $\mathrm{Y}=\mathrm{b}+\mathrm{ax}$ & $\mathrm{Y}=0.08+$ & $\mathrm{Y}=0.0363+$ & $\mathrm{Y}=0.0587+$ & $\mathrm{Y}=0.0415+$ & $\mathrm{Y}=0.0684+$ & $\mathrm{Y}=0.004+$ \\
$0.0353 \mathrm{x}$ & $0.0465 \mathrm{x}$ & $0.0463 \mathrm{x}$ & $0.0247 \mathrm{x}$ & $0.0057 \mathrm{x}$ \\
\hline
\end{tabular}

$\mathrm{x}$ is Concentration of drug $\left(\mathrm{mg} \mathrm{ml}^{-1}\right)$

Table 2: Precision and Accuracy studies of the different methods developed for the essay of EZP.

\begin{tabular}{|c|c|c|c|c|c|c|}
\hline & A & $\mathrm{B}$ & $\mathrm{C}$ & $\mathrm{D}$ & $\mathrm{E}$ & $\mathrm{F}$ \\
\hline $\begin{array}{l}\text { Amount Taken } \\
\quad\left(\mu \mathrm{g} \mathrm{ml}^{-1}\right)\end{array}$ & $\begin{array}{c}4 \\
8 \\
12 \\
16 \\
\end{array}$ & $\begin{array}{c}4 \\
8 \\
12 \\
16 \\
\end{array}$ & $\begin{array}{c}4 \\
8 \\
12 \\
16 \\
\end{array}$ & $\begin{array}{c}4 \\
8 \\
12 \\
16 \\
\end{array}$ & $\begin{array}{c}4 \\
8 \\
12 \\
16 \\
\end{array}$ & $\begin{array}{l}20 \\
30 \\
40 \\
50 \\
\end{array}$ \\
\hline $\begin{array}{l}\text { Amount Found } \\
\qquad\left(\mu \mathrm{g} \mathrm{ml}^{-1}\right)\end{array}$ & $\begin{array}{c}3.997 \\
8.01 \\
12.007 \\
16.04\end{array}$ & $\begin{array}{c}4.011 \\
7.98 \\
12.002 \\
15.94\end{array}$ & $\begin{array}{c}3.97 \\
8.005 \\
12.08 \\
15.96\end{array}$ & $\begin{array}{c}3.99 \\
8.001 \\
12.08 \\
15.97\end{array}$ & $\begin{array}{c}4.004 \\
7.92 \\
11.92 \\
16.13\end{array}$ & $\begin{array}{c}4.02 \\
7.94 \\
11.93 \\
16.08\end{array}$ \\
\hline$\%$ Recovery & $\begin{array}{c}99.93 \\
100.13 \\
100.06 \\
100.25\end{array}$ & $\begin{array}{c}100.28 \\
99.78 \\
100.02 \\
99.65\end{array}$ & $\begin{array}{c}99.3 \\
100.07 \\
100.7 \\
99.78\end{array}$ & $\begin{array}{c}99.69 \\
100.02 \\
100.65 \\
99.83\end{array}$ & $\begin{array}{c}100.12 \\
99.02 \\
99.34 \\
100.82\end{array}$ & $\begin{array}{c}100.5 \\
99.2 \\
99.4 \\
100.55\end{array}$ \\
\hline RSD $\%$ & 0.135 & 0.278 & 0.58 & 0.424 & 0.81 & 0.71 \\
\hline Mean \pm SD & $100.1 \pm 0.13$ & $99.93 \pm 0.28$ & $99.96 \pm 0.58$ & $100.05 \pm 0.4$ & $99.82 \pm 0.8$ & $99.9 \pm 0.88$ \\
\hline $\operatorname{Ref}[7]$ Mean \pm SD & $99.49 \pm 0.88$ & $99.49 \pm 0.88$ & $99.49 \pm 0.88$ & $99.49 \pm 0.88$ & $99.49 \pm 0.88$ & $99.49 \pm 0.88$ \\
\hline t-test & 1.17 & 0.84 & 0.81 & 1.02 & 0.51 & 0.68 \\
\hline F-test & 0.024 & 0.0998 & 0.43 & 0.23 & 0.84 & 0.66 \\
\hline
\end{tabular}

Table 3 : Application of proposed method for the analysis of the EZP in pharmaceutical form.

\begin{tabular}{|c|c|c|c|c|c|c|}
\hline Lunesta $3 \mathrm{mg} / \mathrm{Tab}$. & A & B & $\mathrm{C}$ & $\mathrm{D}$ & E & $\mathrm{F}$ \\
\hline $\begin{array}{l}\text { AmountTaken } \\
\left(\mu \mathrm{g} \mathrm{ml}^{-1}\right)\end{array}$ & $\begin{array}{c}4 \\
8 \\
12 \\
16 \\
\end{array}$ & $\begin{array}{c}4 \\
8 \\
12 \\
16 \\
\end{array}$ & $\begin{array}{c}4 \\
8 \\
12 \\
16 \\
\end{array}$ & $\begin{array}{c}4 \\
8 \\
12 \\
16 \\
\end{array}$ & $\begin{array}{c}4 \\
8 \\
12 \\
16 \\
\end{array}$ & $\begin{array}{c}4 \\
8 \\
12 \\
16 \\
\end{array}$ \\
\hline $\begin{array}{l}\text { Amount Found } \\
\left(\mu \mathrm{g} \mathrm{ml}^{-1}\right)\end{array}$ & $\begin{array}{c}3.98 \\
7.98 \\
12.007 \\
16.06\end{array}$ & $\begin{array}{c}3.96 \\
8.03 \\
11.95 \\
15.94\end{array}$ & $\begin{array}{l}4.005 \\
8.005 \\
11.96 \\
15.96\end{array}$ & $\begin{array}{c}4.005 \\
7.98 \\
11.98 \\
16.01\end{array}$ & $\begin{array}{c}3.98 \\
7.98 \\
12.02 \\
15.96\end{array}$ & $\begin{array}{c}3.986 \\
7.98 \\
12.03 \\
16.14\end{array}$ \\
\hline Recovery \% & $\begin{array}{c}99.57 \\
99.705 \\
100.06 \\
100.4\end{array}$ & $\begin{array}{c}99.15 \\
100.41 \\
99.58 \\
99.65\end{array}$ & $\begin{array}{c}100.12 \\
100.07 \\
99.72 \\
99.78\end{array}$ & $\begin{array}{c}100.13 \\
99.78 \\
99.81 \\
100.09\end{array}$ & $\begin{array}{c}99.52 \\
99.77 \\
100.16 \\
99.74\end{array}$ & $\begin{array}{c}99.66 \\
99.77 \\
100.26 \\
100.9\end{array}$ \\
\hline RSD \% & 0.36 & 0.52 & 0.2 & 0.182 & 0.27 & 0.56 \\
\hline Mean \pm SD & $\begin{array}{c}99.92 \pm \\
0.36\end{array}$ & $\begin{array}{c}99.7 \pm \\
0.52\end{array}$ & $\begin{array}{c}99.93 \pm \\
0.199\end{array}$ & $\begin{array}{c}99.95 \pm \\
0.181\end{array}$ & $\begin{array}{c}99.8 \pm \\
0.27\end{array}$ & $\begin{array}{c}100.15 \pm \\
0.56\end{array}$ \\
\hline Ref Mean $\pm \mathrm{SD}[7]$ & $\begin{array}{c}99.49 \pm \\
0.88\end{array}$ & $\begin{array}{c}99.49 \pm \\
0.88\end{array}$ & $\begin{array}{c}99.49 \pm \\
0.88\end{array}$ & $\begin{array}{c}99.49 \pm \\
0.88\end{array}$ & $\begin{array}{c}99.49 \pm \\
0.88\end{array}$ & $\begin{array}{c}99.49 \pm \\
0.88\end{array}$ \\
\hline $\mathrm{t}$-Test & 0.806 & 0.367 & 0.84 & 0.9 & 0.59 & 1.13 \\
\hline F-Test & 0.168 & 0.35 & 0.051 & 0.04 & 0.09 & 0.41 \\
\hline
\end{tabular}

The stoichiometric ratio between Eszopiclone and potassium permanganate was evaluated by limiting logarithmic method [9]. In this method two sets of experiments were performed. In the first set the concentration of EZP was varied keeping a constant concentration of $\mathrm{KMnO}_{4}$, while in the second set, the concentration of EZP was kept constant and the $\mathrm{KMnO}_{4}$ concentration was varied. Log absorbance versus log [EZP] or [KMnO ] (Fig. 3) was plotted to evaluate the slopes of the respective lines. The slope was found to be unity in each case thus indicating the molar combining ratio of 1:1 between Eszopiclone 
and potassium permanganate. The literature survey reveals that Eszopiclone undergoes oxidation at methylated $\mathrm{N}$ of piperizine ring, $4-\mathrm{N}\left(\mathrm{CH}_{3}\right)$, to its $\mathrm{N}$ oxide viz., 4- $\mathrm{N}\left(\mathrm{CH}_{3}\right) \circledR \mathrm{O}[10]$.

\section{Formation constants}

The formation constant was also estimated from Job's plot by following method described by Likussa and Boltz [11], and Momoki etal [12].The method involves drawing the tangents at the origin of Job's plot from both side and the absorbance at intersection point is taken for $100 \%$ complexation. The absorbance at peak height of Job's plot is taken for $(100-\mathrm{x}) \%$ where $\mathrm{x}$ is the $\%$ degree of dissociation of the complex. The instability constant, $\mathrm{K}^{\prime}=\mathrm{Cx}^{2} /(100-$ $\mathrm{x}$ ) is calculated, where $\mathrm{C}$ is concentration of drug used for Job's method. The reciprocal of $\mathrm{K}^{\prime}$ is the required stability constant $\mathrm{K}$.

Formation constant for method $\mathrm{E}$

Formation constant $(\mathrm{K})$ has been evaluated by using Benesi-Hikdebrand equation[13]

$$
\left[\mathrm{A}_{0}\right] / \mathrm{d}=1 / \mathrm{K}\left[\mathrm{D}_{0}\right] \mathrm{e}+1 / \mathrm{e}
$$

where $\mathrm{d}$ is absorbance, $\mathrm{e}$ is the molar absorbtivity, $\mathrm{A}_{0}$ and $\mathrm{D}_{0}$ are initial concentrations of acceptor $\left[\mathrm{I}_{2}\right]$ and donor $[\mathrm{drug}]$ respectively. A plot of $\left[\mathrm{A}_{0}\right] / \mathrm{d}$ Vs $1 /\left[\mathrm{D}_{0}\right]$ yields a straight line whose slope and intercept gives the value of $\mathrm{K}$.

Optimization of the factors effecting the absorbance.

The factors effecting the absorbance of ion pair complexes like $p \mathrm{H}$ and volume of the dye, in methods $\mathrm{A}, \mathrm{B}, \mathrm{C}$ and $\mathrm{D}$, have been optimized. $1.8 \mathrm{ml}$ of

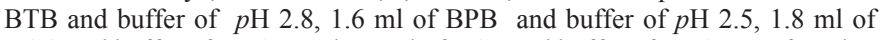
BCG and buffer of $p \mathrm{H} 3.5$ and $1.7 \mathrm{ml}$ of $\mathrm{BCP}$ and buffer of $p \mathrm{H} 2.5$ are found to ne optimal for methods A.B,C and D respectively. However $5 \mathrm{ml}$ of each dye is used, at optimal $p \mathrm{H}$, in the study to ensure complete extraction of the drug. Similarly the $1 \mathrm{ml}$ of iodine for method $\mathrm{E}$ and $1 \mathrm{ml}$ of $\mathrm{KMnO}_{4}, 1 \mathrm{ml}$ of 0.45 $\mathrm{NaOH}$ are found to be optimal and hence are used in the study.

Validation of the proposed methods

The proposed method have been validated in terms of guideline proposed by ICH [14] viz., selectivity, specificity, accuracy, precision, limits of calibration curve, LOD, LOQ, robustness, ruggedness and regression equation. The student $\mathrm{t}$-test and variance $\mathrm{F}$-test have been performed in comparison with a reference method. Table 1A summarizes the values for Beer's law limits, molar absorptivity, regression equation, correlation coefficients, relative standard deviation and recoveries. To test the reproducibility of the proposed methods, six replicate determinations of $12.5 \mu \mathrm{g} \mathrm{ml}^{-1}$ of EZP were made. The coefficient of variation was found to be less than $1.2 \%$ for all the procedures.

The proposed methods have been successfully applied to the determination of EZP in pharmaceutical preparations. The result obtained and shown in Table $1 \mathrm{C}$ were compared to those obtained by a reference method [7] by means of $t$-test at $95 \%$ confidence level. In all cases, the average results obtained by proposed methods and reference method were statistically identical, as the difference between the average values had no significance at $95 \%$ confidence level.

The proposed methods are simple, sensitive and reproducible and can be used for routine analysis of EZP in pure form and in formulation.

\section{ACKNOWLEDGEMENTS}

The authors are grateful to the Head of the Department Chemistry and to the Principal, Nizam College for providing facilities. MC is thankful to UGC for FDP fellowship. TV is thankful to Sri M. Ravindra Reddy, Chairman, Managing Committee SAP College, Vikarabad for providing facilities and to the UGC for financial assistance under Major Research Project.

\section{REFERENCES}

1. C.S. Mc. Crae, A. Ross, A. Stripling, N.D. Dautovich, Clin Interv Aging, 2, 313, (2007)

2. G.S.Jufe, Vertex, 16, 294, (2007).

3. K. Anandakumar, G. Kumaraswamy, T. Ayyappan, A.S.K. Sankar, D. Nagavalli, Res. J. Pharm.Tech, 3, 202, (2010).

4. M. Meng, L. Rohde, V. Capka, P. Bennett, Chiral Chromatographic Method, 1, (2007).

5. K. Anandakumar, G. Kumaraswamy, T. Ayyappan, A.S.K. Sankar, D. Nagavalli, Asian J.Res.Chem, 3, 63, (2010).

6. R.N. Kumar, G.N. Rao, P.Y. Naidu, Asian J.Res.Chem, 3, 374, (2010).

7. R. Sunil, Dhaneshwar, K. Vidhya, Bhusari, Int. J. ChemTech. Res, 3. 680, (2011).
8. P. Job, Anal. Chim., 9, 113 (1928).

9. N. Rehman, M. Kashif, Japan Soc. Anal. Chem, 19, 907 (2003).

10. Yu Sha, Lei Zhang, Gui-Jie Du, Jian Ren, Mao-Sheng Cheng, Molecules, 13, 1817, (2008).

11. W. Likussar D.F. Boltz, Anal. Chem., 43, 1265, (1971).

12. K. Momoki, J. Sekino, H. Sato, N. Yamaguchi, Anal. Chem., 41, 1286, (1969).

13. H A Benesi and J R Hildebrand, J Am Chem Soc, 71, 2703 (1949)

14. International Conference on Harmonization (ICH) of Technical Requirement for the Registration of Pharmaceuticals for Human use, Validation of analytical procedures: definitions and Terminology Genera (1996). 